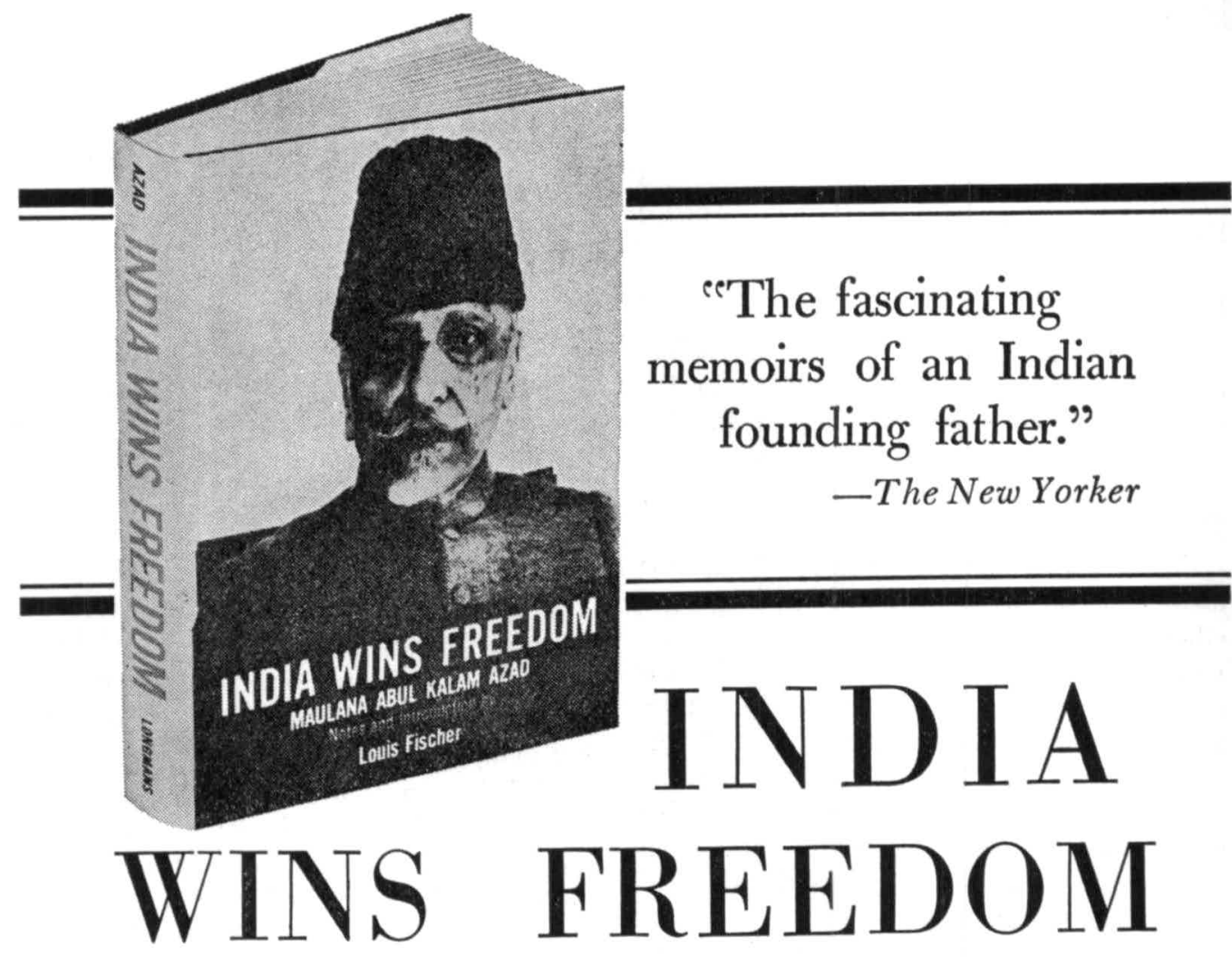

by MAULANA ABUL KALAM AZAD

With an Introduction and Notes by Louis Fischer. The first-person narrative of the birth of a nation by a man who, with Gandhi and Nehru, was a leader in the struggle for Indian freedom and who, though a Moslem, tried to avert the partition of India.

"Fascinating and deeply moving... The significance of this book, which caused a sensation when it appeared in India shortly after Azad's death, is that here a great Muslim, ten years after the wrenching experience of partition, recollects, but not in tranquillity, the defeat of what had been his life's dreamthe peaceful liberation from British rule of a united India . . . This defeat Maulana Azad attributes to a fateful decision by Nehru to whom, nevertheless, he dedicates this book."-Vera Micheles Dean, N. Y. Herald Tribune

"The Maulana's singleness of purpose, his perspicacity, his stoicism and his magnanimity shine through the pages."-Geofrrey GodselL, Christian Science Monitor

"Forthright ... Throws a flood of light on the independence movement and the men who played a significant part in it."-RANJEE Shahani, Saturday Review

"A closeup of a man who seems to have found a way to combine successfully practical statesmanship and the heard voice of conscience." - Ralph Block, Washington Post

$$
\text { Illustrated - At all bookstores } \$ 6.00
$$

LONGMANS, GREEN \& COMPANY, INC., NEW YORK 18 


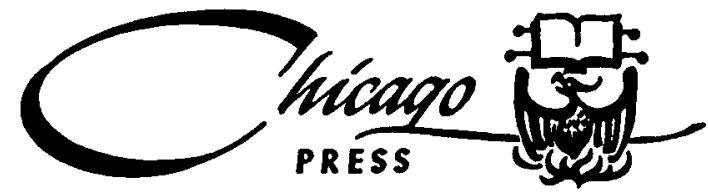

\section{NEW ZEALAND BECOMES A PACIFIC POWER}

By Bernard K. Gordon. Focusing on the decade between 1937 and 1947, this study shows how the threat and later the reality of Japanese aggression changed New Zealand from a disinterested observer on the fringes of the international scene to an active participant in Asian and world affairs.

$\$ 6.5^{\circ}$

\section{JAPAN'S AMERICAN INTERLUDE}

By Kazuo Kawai. For the first time in English, the story of the American Occupation of Japan from the Japanese point of view.

$\$ 5.00$

\section{POPULATION AND PROGRESS IN THE FAR EAST}

By Warren S. Thompson. Shows clearly how economic, political, and demographic aspects of life in the Far East bear directly on each other to influence each nation's cultural patterns and, in turn, its relationships with the rest of the world. $\$ 7.5^{\circ}$

\section{VILLAGE JAPAN}

By Richard K. Beardsley, John W. Hall, and Robert E. Ward. "The best and most detailed study of a Japanese social microcosm that has ever been produced in a Western language."

-EDWIN O. REISCHAUER 


\title{
Indonesian Independence and the United Nations
}

\author{
By ALASTAIR M. TAYLOR
}

A DETAILED examination of the machinery of the United Nations in action is long overdue, and Dr. Taylor's work is doubly welcome, both as the first thorough case study of pacific settlement by the world organization and as a contribution of peculiar relevance to the 1960's, since in the handling of the Indonesian question the whole colonial issue can be seen in microcosm. What happened in Indonesia is pertinent for all other "colonial" areas today.

530 pages. Price to be announced.

U.S. RIGHTS ONLY

\section{The Chinese of Semarang}

\section{A Changing Minority Community in Indonesia}

\author{
By DONALD E. WILLMOTT, University of Saskatchewan
}

THIS is a community study of a minority group in a rapidly changing non-Western, urban setting. It describes and analyzes various aspects of community life among the Chinese of Semarang, such as occupations and economic activities, ethnic group relations, community organization, leadership, education, religion, and family life. 368 pages, $\$ 5.75$

\section{Major Governments of Asia}

\section{Edited by GEORGE McT. KAHIN, Cornell University}

"THE five authors of the present work have met the basic requirements of clear writing, factual accuracy, scholarly objectivity, and sound suggestive judgment. Apart from its value as an undergraduate textbook, Major Governments of Asia will be a handy addition to the reference library of any scholar concerned with contemporary Asia."-Journal of Asian Studies

620 pages, maps, charts.

Educational edition, $\$ 5.50$

\section{CORNELL UNIVERSITY PRESS}

124 Roberts Place, Ithaca, New York 


\section{CHINESE PAINTING}

Leading Masters and Principles

Part II-The Later Centuries OSVALD SIRÉN

Part II of this definitive work traces and interprets Chinese painting from the Yüan and Ming periods to the reign of the Emperor Ch'ien-lung. Written by a foremost authority on Chinese art, it offers a stunning array of 464 collotype plates, $I_{2}$ halftones, and 2 fullcolor plates. Format $83 / 4 \times 11$.

Part II, 4 Volumes, boxed: \$105.

Parts $I$ and $I I, 7$ Volumes: \$210.

\section{4,000 YEARS OF CHINA'S ART \\ DAGNY CARTER}

The product of a lifetime of study, this book traces the development of Chinese painting, sculpture, pottery, textiles, and architecture from their earliest origins to the present. "Presents the unparalleled achievements of Chinese art authentically, perceptively, and with a surprising amount of detail."-ART Digest. "Readable, yet scholarly . .."-HaRry A. Broadd, University of Tulsa. Rev. Print., 195I. 358 pp.; 239 photographs and illustrations.

$\$ 7.50$

\section{GARDENS OF CHINA}

\section{OSVALD SIREN}

An authoritative treatment of Chinese garden art. Book presents the fundamental features and compositional elements of Chinese gardens and offers historical and descriptive additions-many supported by quotations from older Chinese writings. "Sympathetic, well documented, beautifully illustrated ... a delightful and comprehensive introduction." -Artibus Asiae. 1949. 363 pp.; 294 ills.

\section{THE GARDEN FLOWERS OF CHINA}

\section{H. L. LI, University of Pennsylvania}

This handsomely illustrated book brings together a wealth of information about many of our best-known garden flowers-from peonies, orchids, roses, and lilies to flowering trees, shrubs, and vines. For each flower, the author translates the Chinese name, explains its symbolic use in Chinese homes and gardens, and its introduction to the West. Chronica Botanica: An International Biological and Agricultural Series, No. 19. 1959. 257 pp.; 68 ills.

$\$ 6.50$

\section{ENNIN'S TRAVELS}

\section{IN T'ANG CHINA}

EDWIN O. REISCHAUER, Harvard University

A fascinating account of the extraordinary civilization that existed in $\mathbf{T}^{t}$ ang China four centuries before Marco Polo visited that country. Based on the diary kept by the Japanese Buddhist monk, Ennin, the book skillfully interweaves background materials from Chinese dynastic histories and records of the Japanese court to describe life in ninth-century China. By the translator of EnNin's Diary. 1955. 34 I pp., Illus.

$\$ 6.00$

\section{THE INVENTION OF PRINTING IN CHINA AND ITS SPREAD WESTWARD}

\section{THOMAS E. CARTER; Revised bY L. CARRINGTON GOODRICH, Columbia University}

The standard authority on the Chinese origins of printing. This book uncovers the obscure beginnings of block printing in Buddhist and Taoist monasteries; traces the possible channels of its transmission through central Asia and the Islamic world to Europe. " $A$ brilliant synthesis." - FAR EASTERN QUARTERLY. 2nd Ed., 1955. 293 pp.; 32 ills.

$\$ 10.00$

\section{THE CHINESE LANGUAGE \\ BERNHARD KARLGREN, University of Stockholm}

A brilliant and stimulating essay on the nature and history of the Chinese language. Book discusses the important elements of written and spoken Chinese; explains the developmental processes that have made it what it is today. "For the many who wish to know something of the language . . . as a manifestation of the genius and soul of the Chinese people."-ARTIBUS AsIAE. 1949. 122 $p p$.

$\$ 4.00$

\section{THE KOREANS}

\section{AND THEIR CULTURE}

\section{CORNELIUS OSGOOD, Yale University}

An objective survey of Korea from the nation's earliest beginnings to the climactic events of 1950 . A highlight of the volume is the author's first-hand study of a Korean village-an enlightening contribution to an understanding of Korean life and customs. "Written with conciseness, precision, and charm . . "-FAR EASTERN SURVEY, 195I. 387 pp.; 67 maps, ills.

$\$ 6.50$

\section{The Ronald PRess Company}




\section{JAPAN QUARTERLY}

Japan's leading quarterly review; a basic necessity for anyone who is seriously interested in what Japan is doing and thinking. JAPAN QUARTERLY carries a wide range of articles by leading authorities on social problems, economics, politics, art and literature. In addition, every issue contains expertly translated stories and essays by top-flight Japanese writers. Since it was first issued in 1954, JAPAN QUARTERLY has become internationally recognized as the most authoritative journal of its type in Japan.

Published by

ASAHI SHIMBUN-SHA, Tokyo, Japan

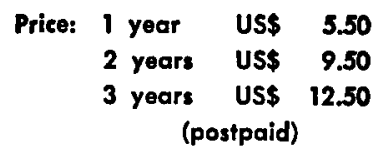

All back files are available

\section{THE AMERICAN \\ SOCIOLOGICAL REVIEW}

Journal of the American Sociological Association

An authoritative publication devoted to the social sciences

Selects and publishes the best writings in the field.

Reflects new trends and developments in theory and research.

Reports on subjects of current significance.

Reviews the important new books on sociology and related subjects.

Bi-monthly-Subscriptions are included in membership in the ASSOCIATION

$\$ 8.00$ per year to non-members

THE AMERICAN SOGIOLOGICAL ASSOCIATION

New York University

Washington Square

New York 3

New York 


\section{The People of Alor}

By Cora Du Bois. Originally published in 1944, The People of Alor proved itself one of the most reliable, useful, and creative works on culture and personality. A study of the individual and ethnic traits of the inhabitants in a small, comparatively self-contained Indonesian island, it employed a new, interdisciplinary approach that has been the prototype of many later studies. In the present edition, an important new introductory chapter relates the original research to subsequent developments in sociology. Illustrated.

\section{From Empire to Nation}

\section{THE RISE TO SELF-ASSERTION OF ASIAN AND AFRICAN PEOPLES}

By Rupert Emerson. "Mr. Emerson writes with a rare effort at impartiality and does not gloss over the difficult problems involved ... His thoughtful book will help the reader understand what is happening in our day for the first time on a global scale." N. Y. Times Book Review

\section{Studies in the Ching Administration}

By John King Fairbank and Ssu-yü Teng. This pioneering examination of the Ch'ing bureaucracy remains the most detailed account of the official business of the day and is essential to the discussion of the more general issues raised by social sciences. It is hoped that this reprint will spur further research to build a clear picture of the stillvague conception of the official establishment.

$\$ 5.00$

\section{Japanese Sculpture of the Tempyo Period}

\section{MASTERPIECES OF THE EIGHTH CENTURY}

By Langdon Warner. Edited and arranged by James Marshall Plumer. This magnifcent set consists of a 160-page volume of commentary and description and a collection of 219 collotype plates $(12 \times 151 / 4)$ encased in a brocade-covered wooden box especially made in Japan for this limited edition.

$\$ 50.00$

\section{The Mag Fourth Movement \\ INTELLECTUAL REVOLUTION IN MODERN CHINA}

By Chow Tse-tsung. In protest against Japanese demands and the decisions of Versailles in 1919, the young Chinese intellectuals, steeped in Western ideas, initiated a reform movement which culminated in the incident of May 4, 1919. Without understanding this complex development and its contribution to the rise of Chinese nationalism and communism, recent Chinese history remains a closed book.

$\$ 10.00$

\section{Studies on the Population of Chiva, $1368-1953$}

By Ping-ti Ho. In this exhaustive study and interpretation of China's population, Dr. Ho "has put all future workers on this subject in his debt," says John K. Fairbank. Through an intimate knowledge of his subject, and long research, the author has succeeded in clearing up much of the confusion which has always attended interpreting China's multitudes on a historical basis.

$\$ 6.00$ 


\title{
d
}

\section{Tradition, Values, \& Socio-Economic Development}

\author{
edited by Ralph Braibanti and Joseph J. Spengler
}

In this series of nine analytical essays, Melville J. Herskovits, Bert F. Hoselitz, Wilbert E. Moore, John D. Montgomery, I. H. Qureshi, Mason Wade, Joseph J. Spengler, and Ralph Braibanti explore the effect of tradition and values on modernization in selected Commonwealth countries, especially India, Pakistan, Canada, the Union of South Africa, and certain Southeast Asian countries. Published for the Duke University Commonwealth-Studies Center.

$\$ 6.00$

\section{Russian \& Soviet Policy in Manchuria \& Outer Mongolia, 1911-1931}

\author{
by Peter S. H. Tang
}

"This book is in the classical tradition of diplomatic history. . . . Dr. Tang is to be commended for the immense labor reflected in his voluminous footnotes and his detailed account."-Far Eastern Survey

$\$ 10.00$

\section{DUKE UNIVERSITY PRESS, DURHAM, N. C.}

\section{INDIA QUARTERLY}

\section{(A Journal of International Affairs)}

Published quarterly by the Indian Council of World Affairs, New Delhi, it is devoted to the objective study and discussion of current Indian and international political, economic and defence problems. India Quarterly is now in its sixteenth year of publication.

Annual Subscription $\$ 2.80$ or 20s. post free

Please send subscription order to:

ASIA PUBLISHING HOUSE

$\left.\begin{array}{c|c}\text { Irg West 57th St. } \\ \text { NEW YORK I9 }\end{array} \mid \begin{array}{c}\text { Nicol Road } \\ \text { BOMBAY-r }\end{array}\right\} \begin{gathered}447 \text { Strand } \\ \text { LONDON W.C.2 }\end{gathered}$




\section{Important \\ CALIFORNIA \\ Fall Books... \\ MARCO POLO'S ASIA}

1/ By Leonardo Olschki. Translated from the Italian by John A. Scott, this first systematic appraisal of Polo's historianship is recognized as the most perceptive and comprehensive study yet made of Polo. It thoroughly and critically explores the principal aspects of Oriental civilization as Polo portrayed them in his own time.

$\$ 10.00$

\section{A HISTORY OF CHINA}

|| By Wolfram Eberhard. Now revised extensively throughout, this is a comprehensive survey of Chinese history. "The best existing guide to Chinese sociopolitical history as a whole ... based on sound scholarship, and it is readable." Pacific Affairs.

$\$ 5.00$

\section{THE YEAR OF MY LIFE:}

\section{A TRANSLATION OF ISSA'S ORAGA HARU}

By Nobuyuki Yuasa. Written by one of the greatest masters of Japanese haiku, this work is the autobiographical record of what Issa heard, thought, and felt in the year 1819, an archetypal year that serves as a symbol for his entire life.

Paper $\$ 1.25$

At your bookseller or

\section{University of California Press} $\|$ Berkeley 4 
ROYAL ASIATIC SOCIETY

OF GREAT BRITAIN

AND IRELAND

(Founded 1823)

56 Queen Anne Street, London, W. 1

THE SOCIETY'S JOURNAL contains original articles on the archaeology, art, history, language, literature, beliefs and customs of the East as well as reviews of books dealing with those topics.

Applications for membership of the Society should be sent to the Secretary at the above address.

The annual subscription for Fellows is \&3. 3 s.

Libraries and non-members can obtain the Journal (approximately 300 pp.) post-free for $£ 3$ p.a. (trade price $£ 2$. 1 os.) or single copies for $£ 1$. 16 s. (trade price $£ 1$ los.) payable to the Secretary in advance.

Taken by libraries in all Continents, the Journal accepts advertisements at the following rates for each insertion: for a full page $£ 5$, a half-page $£ 2$. 10 s., and a quarter-page $£ 1.5^{s}$. 


\section{A HISTORY OF JAPAN $1334-1615$}

\section{George Sansom}

This is the second volume of a monumental work by the West's most distinguished scholar of Japanese history. A History of Japan, 1334-1615 describes the growth of a new feudal hierarchy, the ebb and flow of civil war, the rise and fall of great families, and the development amidst extreme political disorder of remarkable new features in Japanese institutional and economic life. This is the period of Japan's expanding relations with other parts of Asia, and the arrival of traders and missionaries from European countries. Illustrated with photographs, drawings, and maps.

$\$ 8.25$

\section{A HISTORY OF JAPAN TO 1334}

George Sansom

This volume describes the growth from tribal origins of an organized state, examines the conflict between the nobility and the gentry, and traces the evolution of Japan's feudal system.

"This work will be the standard history of Japan for all serious students."-The American Historical Review

"It is not likely to be equalled in our generation."-The Canadian Historical Review

"Not likely to be superseded. . . . An impressive achievement."The Times Literary Supplement (London)

"A landmark in the history of Japanese studies."-The Christian Science Monitor

Order from your bookstore, please

\section{Stanford University Press}




\title{
STANFORD STUDIES IN THE CIVILIZATIONS OF EASTERN ASIA
}

\section{THE CONFUCIAN PERSUASION}

Edited by Arthur F. Wright

An exploration of Confucianism in widely different spheres of thought and action.

\section{BUDDHISM IN CHINESE HISTORY}

\author{
Arthur F. Wright
}

"A sound, well-balanced and well-written account of the present state of knowledge and opinion (as related to) internal history."-The Times Literary Supplement (London)

\section{CONFUCIANISM IN ACTION}

Edited by David S. Nivison and Arthur F. Wright

"An admirable symposium on Chinese tradition and institutions." - The Pacific Historical Review

\section{THE AGRARIAN ORIGINS OF MODERN JAPAN}

\section{Thomas C. Smith}

1959 Borden Award, Hoover Institution on War, Revolution, and Peace. "One of the most valuable studies of Japanese history."-The Journal of Economic History

Order from your bookstore, please Stanford University Press 
The only American quarterly devoted exclusively to Middle Eastern Affairs

THE

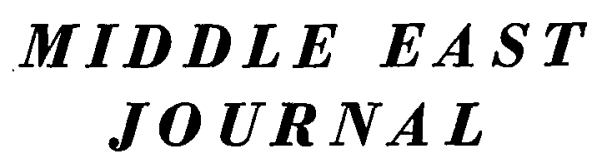

ARTICLES, BOOK REVIEWS, BIBLIOGRAPHY, CHRONOLOGY, SIGNIFICANT DOCUMENTS

YEARLY SUBSCRIPTION: \$6 (2 years, \$11). UNESCO COUPONS ACCEPTED.

Please address inquiries and subscription requests to

\section{THE MIDDLE EAST INSTITUTE}

1761 N. St., N. W.

Washington 6, D. C.

\section{ANNOUNCEMENT}

The thirteenth annual meeting of the Association for Asian Studies will be held at the Palmer House, Chicago, March 27-29, 1961. 


\section{BOLLINGEN SERIES Books on the Cultures of Asia}

\section{THE I CHING, OR BOOK OF CHANGES}

Translated by Richard Wilhelm and Cary F. Baynes. With a foreword by C. G. Jung. One of the five classics of Confucianism.

Two volumes, boxed: $\$ 10.00$

\section{CHANGE: EIGHT LECTURES ON THE I CHING}

By Hellmut Wilhelm. Translated from the German by Cary F. Baynes. Studies on the Book of Changes by a leading Orientalist. Indexed.

\section{MUDRA}

\section{A Study of Symbolic Gestures in Japanese Buddhist Sculpture}

By E. Dale Saunders. A discussion of the history and symbolism of the hand postures used in Buddhist ritual and iconography. With 110 line drawings, 4 diagrams and 26 halftone plates displaying sculpture from Japan and elsewhere.

\section{THE TAO OF PAINTING}

By Mai-Mai Sze. A study of the ritual disposition of Chinese Painting, with the first English translation of the famous Mustard Seed Garden Manual of Painting (1679-1701). With 428 illustrations from the Manual, illustrating brushstrokes; 12 gravure plates, 2 in color; and an essay exploring the ideas that have motivated and governed Chinese painting. Indexed.

Two volumes, Boxed: $\$ 25.00$

\section{PHILOSOPHIES OF INDIA}

By Heinrich Zimmer. Edited by Joseph Campbell. A comprehensive survey of one of the most ancient and influential philosophical traditions. 12 plates. Indexed.

\section{ZEN AND JAPANESE CULTURE}

By Daisetz T. Suzuki. Aspects of Japanese art and life which have been influenced by the school of Zen Buddhism, including the Samurai, swordsmanship, the tea ceremony, gardening, the No play, painting, and poetry. With 69 collotype plates. Indexed.

$\$ 8.50$

BOLLINGEN SERIES, distributed by Pantheon Books Inc., 333 Sixth Ave., New York 14, N. Y. For detailed catalogue write to Bollingen Series, 140 E. 62 Street, New York 21, N. Y. 


\section{MONOGRAPHS OF THE ASSOCIATION FOR ASIAN STUDIES}

\section{Carrington Goodrich, Editor}

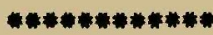

\section{MONEY BCONOMY IN MEDIEVAL JAPAN}

A study in the use of coins, by Delmer M. Brown. 1951. viii, 128 pp. Bibliography. Cloth $\$ 2.50$

\section{CHINA'S MANAGEMENT OF THE AMERICAN BARBARIANS}

A study of Sino-American relations, I841-1861, with documents, by Earl Swisher. I95I. xxi, 844 pp. Glossary, bibliography. Cloth $\$ 7.50$

III. LEADERSHIP AND POWER IN THE CHINESE COMMUNITY OF THAILAND

By G. William Skinner. 1958. xvii, 363 Pp., 9 charts. Cloth $\$ 6.50 \quad$ our of PRINT

\section{SIAM UNDER RAMA III, I824-185I}

By Walter F. Vella. 1957. viii, I80 pp., 2 illustrations, 4 maps, appendix, bibliography, index. Cloth $\$ 5.00$

\section{THE RISB OF THE MERCHANT CLASS IN TOKUGAWA JAPAN, I600-I868}

An introductory survey, by Charles David Sheldon. 1958. ix, 200 pp. Glossary, bibliography, index. Cloth $\$ 5.00$

\section{CHINESE SECRET SOCIETIES IN MALAYA}

A survey of the Triad Society from 1800 to 1900 , by L. F. Comber, B.A., F.R.A.S. 1959. viii, 324 pp., I5 illustrations, I map in color, 5 maps, bibliography, index. Cloth $\$ 6.50$

\section{THE TRADITIONAL GHINESE CLAN RULES}

By Hui-chen Wang Liu. 1959. x, 264 Pp., I illustration, 50 tables, bibliography. Cloth $\$ 5.50$

\section{A COMPARATIVE ANALYSIS OF THE JAJMANI SYSTEM}

By Thomas O. Beidelman. 1959. iv, 86 pp, bibliography, index. Cloth \$2.50

IX. COLONIAL LABOR POLICY AND ADMINISTRATION IgIO-I94I

By J. Norman Parmer. 1960. xii, 294 pp., 2 maps, 9 charts, bibliography, index. Cloth $\$ 6.00$

X. BANKGHUAD-A COMMUNITY STUDY IN THAILAND

By Howard Keva Kaufman. 1960. ix, 235 pp., 6 plates, 8 illustrations, glossary, bibliography, index. Coth $\$ 5.50$

Distributed by

\section{J. J. AUGUSTIN PUBLISHER, LOCUST VALLEY, NEW YORK}


